\title{
Controlling Factors Determining the Selective HSCN Addition to Double Bonds and Their Application to the Synthesis of 7-Isothiocyano-7,8- $\alpha$-Dihydro-Bisabolene.
}

\author{
Cecilia M. de Oliveira ${ }^{a, b}$, Cleuza C. da Silva ${ }^{c}$, Carol H. Collins ${ }^{a}$ and Anita J. Marsaioli $^{a *}$ \\ anstituto de Química, Universidade Estadual de Campinas, CP 6154, 13083-970, Campinas - SP, Brazil \\ ${ }^{\mathrm{b}}$ Instituto de Química, Universidade Federal de Goiás, Goiania - GO, Brazil \\ ${ }^{\mathrm{c}}$ Departamento de Química, Universidade Estadual de Maringá, CP 331, Maringá - PR, Brazil
}

\begin{abstract}
A reatividade de duplas ligações terminal e trissubstituída de monoterpenos com HSCN foi examinada por CG evidenciando que fatores cinéticos são responsáveis pela adição quimiosseletiva em duplas ligações terminais em terpenos. O resultado mostra que a adição é cerca de 17 vezes mais rápida em duplas terminais do que em duplas trissubstituídas e que a presença do primeiro grupo SCN impede a entrada de um segundo grupo. A presença de um grupo hidroxila ou metoxila na molécula diminui sensivelmente a velocidade da reação. A partir do estudo acima foi possível elaborar e realizar a síntese do produto natural 7-isothiocyano-7,8-dihydro- $\alpha$-bisabolene em duas etapas a partir do bisabolol.
\end{abstract}

\begin{abstract}
The reactivity of terminal and trisubstituted double bonds of monoterpenes with HSCN has been examined by GC giving evidence that kinetics is responsible for the chemoselective addition to terminal double bonds in terpenes. The results show that the addition to the terminal double bond is about 17 times faster than for trisubstituted double bonds and that the presence of the first $\mathrm{SCN}$ group in the molecule prevents a second addition. The presence of a hydroxyl or methoxy group in the molecule, decreases the reaction kinetics. Based on these kinetic experiments a two steps synthesis of the natural product 7-isothiocyano-7,8-dihydro- $\alpha$-bisabolene using bisabolol as starting material, was planned and successfully accomplished.
\end{abstract}

Keywords: terpenes, HSCN, double bonds, chemoselectivity

\section{Introduction}

Among the sulfur containing natural products the biologically active isothiocyanosesquiterpenes isolated from sponges (order Halicondrida, Axinellida and Littristida) $)^{1,2}$ have attracted the attention of several synthetic chemists. A critical analyses of some isothiocyanosesquiterpene total syntheses ${ }^{3}$ revealed that a good method to selectively introduce the NSC group at a quaternary position was lacking. The addition of the HSCN to double bonds, was successfully applied in our group, to obtain mono and sesquiisothiocyanoterpenes proving to be a straightforward methodology showing regio and chemoselectivity. In some instances stereoselectivity was also observed. From the initial experiments, it was inferred that the observed chemoselectivity could be explained in terms of kinetics but no specific experiments were performed.

\footnotetext{
*e-mail: anita@iqm.unicamp.br
}

Unraveling the chemoselectivity of the HSCN addition to terpenes is the objetive of this present paper.

\section{Results and Discussion}

Limonene (1) and dihydrolimonene (2) were proposed as starting material for the kinetic study of the HSCN addition. These two monoterpenes were considered to be ideal to provide the answers to two basic questions: a) is HSCN addition to a terminal double bond indeed faster? and $\mathbf{b})$ are any double addition products formed in detectable amounts?

The answer to question a is obtained from kinetic experiments. Thus standards of the $\mathbf{3 / 4}$ (thermodynamic products) and 3a /4a (kinetic products) were obtained using the previously described methodology $y^{4,5}$ with a large excess of in situ generated HSCN (Figure 1). All standards were carefully characterized by spectroscopy. Gas chromatographic monitoring of $\mathrm{HSCN}$ addition to an equimolar 
mixture of $\mathbf{1}$ and $\mathbf{2}$ provided a data ensemble (Table 1) that clearly differentiated between a fast terminal and a slow trisubstituted double bond reaction.

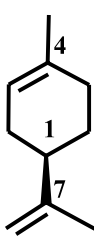

1

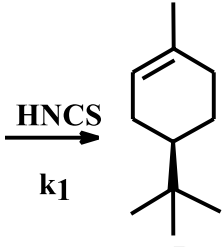

$\mathbf{R}$

$3 \mathbf{R}=\mathbf{N C S}$

$\mathbf{3 a} \mathbf{R}=\mathbf{S C N}$

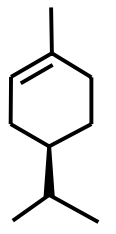

2

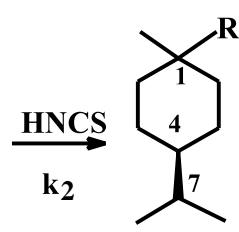

$4 \mathbf{R}=\mathrm{NCS}$ $4 \mathbf{a} R=\mathbf{S C N}$
Figure 1. Addition products of HSCN to Limonene $\mathbf{1}$ and Dihydrolimonene 2

Quantitative treatment of these data could be performed by applying the Sharpless equation ${ }^{6}$ assuming a pseudo first order reaction (HSCN present in large excess).

However, this quantitative method requires accurate evaluation of the conversion extent. This particular information could not be accessed due to serious allergic reactions of the chemists directly and indirectly working in this project while isolating compounds $\mathbf{3}, \mathbf{3 a}, \mathbf{4}$ and $\mathbf{4 a}$. On the other hand, Rakels' equation ${ }^{7}$ (Equation 1) provides an excellent means to evaluate the relative quantities of $\mathrm{k}_{1}$ and $\mathrm{k}_{2}$ and conversion data are not required. This equation was adapted to our experiments taking into consideration that when the GC detector response is corrected for the substrates and for the products they will behave as an enantiomeric pair. Thus using data obtained after $65 \mathrm{~min}$ of reaction, Table $1, \mathrm{E}=\mathrm{k}_{1} / \mathrm{k}_{2}$ and $\mathrm{S}=$ substrate ratio or $\mathbf{2 - 1 /}$ $\mathbf{1}+\mathbf{2}=[43.1-8.3 / 43.1+8.3]$ and $\mathrm{P}=$ product ratio or $(\mathbf{3 + 3 a})(\mathbf{4 + 4 a}) /(\mathbf{3}+\mathbf{3 a})+(\mathbf{4 + 4 a})=[(39.1+4.8) 2.6+1.8) /$ $(39.1+4.8)+(2.6+1.8)]$. Applying Equation 1 to this set of data and to the others revealed that $E$ is about 17 .

Thus the chemoselectivity of HSCN addition to the terminal double bond of $\mathbf{1}$ and other terpenes can be partially explained in terms of kinetics ${ }^{5}$.

$$
E=\frac{k_{1}}{k_{2}}=\frac{\ln [(1-S) /(1+S / P)]}{\ln [(1+S) /(1+S / P)]}
$$

Eq. 1

The answer to question $\mathbf{b}$ came from the fact that no additional products were detected in the reaction monitored by GC and GC/MS. A second factor has to be invoked for the non formation of the double addition products. The literature ${ }^{8}$ has previously reported that in HSCN addition to double bonds, the presence of polar groups play a deactivating role. By monitoring the addition reaction of HSCN to an equimolar mixture of $\mathbf{2}$ and $\mathbf{5}$ during a reaction
Table 1. GC - FID quantification of percentage composition of the HSCN addition reaction to an equimolar mixture of 1 and 2

\begin{tabular}{ccccc}
\hline \multirow{2}{*}{ Compound } & \multicolumn{4}{c}{ Reaction time reagents and products $\%$} \\
\cline { 3 - 5 } & $5 \mathrm{~min}$ & $35 \mathrm{~min}$ & $65 \mathrm{~min}$ & $80 \mathrm{~min}$ \\
\hline $\mathbf{1}$ & 44.5 & 15.6 & 8.3 & 6.0 \\
$\mathbf{2}$ & 43.3 & 42.8 & 43.1 & 47.0 \\
$\mathbf{3}$ & 10.1 & 30.1 & 39.1 & 34.0 \\
$\mathbf{3 a}$ & 1.9 & 6.6 & 4.8 & 7.3 \\
$\mathbf{4}$ & Not det. & 1.5 & 2.6 & 3.6 \\
$\mathbf{4 a}$ & Not det. & 1.3 & 1.8 & 2.0 \\
\hline
\end{tabular}

time of 24 hours, dihydrolimonene (2) was totally consumed while no addition product from terpineol (5) was detected (Figure 2). Consequently the factors determining the chemoselectivity are: a) faster addition to the terminal double bond and b) interference of the first SCN group in the molecule, preventing a second addition.

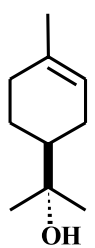

$( \pm)-5$

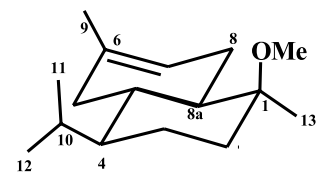

$( \pm)-6$

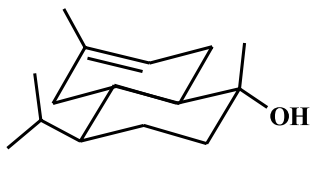

$( \pm)-7$
Figure 2. Terpenes possessing polar groups that did not undergo HSCN addition.

In order to assess the scope of the polar group interference, addition of $\mathrm{HSCN}$ to $( \pm)$ - $O$-methylcadinol (6), cadinol $^{9}$ (7) (equatorial $\left.\mathrm{OH}\right), \operatorname{cadinol}^{9}$ (10) (axial OH), isothiocyanocadinene (13), thiocyanocadinene (14) and (-)-bisabolol ${ }^{10}(8)$ were carried out. Compounds 6, 7, 13 and $\mathbf{1 4}$ did not produce addition products in detectable amounts while (-)-8 produced $\mathbf{9}$ and $\mathbf{9 a}$ and $\mathbf{1 0}$ produced 11 and 11a in 1:1 ratio (Figures 2 and 3). Therefore, polar groups can a priori be divided into two groups:

a) polar groups (e.g. $\mathrm{OH})$ capable of hydrogen 'bonding and located in the vicinity of the double bond which, though decreasing the overall reaction kinetics, can favour one addition among other alternatives. The selective addition to only one of the two trisubstituted double bonds of $\mathbf{8}$ is a good example. Another example is cadinol (10) (Figure 3) which produced 11 and 11a.

b) polar groups which decrease the rate of the addition and provide no counterbalancing effect, so that most of the HSCN is polymerised before any addition occurs (e.g. -OMe group and an $\mathrm{OH}$ group with no appropriate stereochemistry to favour one addition, compounds 6 and 7). The interference of the polar groups was well documented with compounds 6, 7, 8 and 10 but we felt that the interference of the first SCN ought to be better investigated. Thus addition to cadinene (12) (Figure 3) was monitored by GC and GC/MS. 
As expected, addition occurred at the terminal double bond. The reaction solution was then filtered and all the polymerised HSCN was separated. Freshly prepared HSCN was then added to the filtered reaction solution. GC monitoring revealed that the $\mathbf{1 3}$ plus $\mathbf{1 4}$ mixture was transformed into the thermodynamic products $\mathbf{1 3 a}$ and $\mathbf{1 3 b}$ but no double addition occurred. Thus the SCN and NCS groups can be classified as polar substituents belonging to group b. Aiming at the application of these newly acquired insights about HSCN addition to terpenes, the synthesis of 7-isothiocyano-7,8-dihydro- $\alpha$-bisabolene (16), isolated from Halichondria sp. ${ }^{11}$, in two steps from (-) - bisabolol (8), was proposed as a challenging synthetic target (Figure 4). It should be mentioned that the natural product is (+)$1 R, 7 S$ and the use of (-)-(1S,7S)-bisabolol (8) would yield the enantiomeric series. Nevertheless, (-)-bisabolol (8) dehydration ${ }^{12}$ provided a mixture of $\mathbf{1 5}, \mathbf{1 5 a}$ in a 1.5:1 ratio based on GC and ${ }^{1} \mathrm{H}$ NMR data, $[\delta 4.73$ (H-14 of 15), 5.00 (H-8 (15a) and H-10 (15 and 15a)]..$^{13}$

No attempts were made to separate these structurally related isomers since according to our results only compound 15, possessing the terminal double bond would react rapidly and the remaining hydrocarbons would be easily separated by chromatography after the reaction. This indeed occurred and the addition products 16 and $\mathbf{1 6 a}$ were obtained in $47 \%$ yield. If one considers that $\mathbf{1 5}$ was only
$60 \%$ of the starting material (obtained by GC analysis) the calculated yield is $77 \%$. Comparison of the spectroscopic data of the synthetic 16a and of the natural product showed equal proton and C-13 chemical shifts which is expected for enantiomeric pairs thus confirming the synthetic success.

Finally it can be concluded that Eq. 1 allows relative quantitative evaluation of a reaction kinetics by GC/FID after calibration response of the reagents and the products. There is no need to carry the reaction to completion.

Application of Eq. 1 to our data revealed that HSCN addition to terminal double bonds is faster and responsible for the chemoselectivity. The polar group interference in the HSCN addition to terpenes was assessed through four additional reactions and the synthesis of 7-isothiocyano7,8-dihydro- $\alpha$-bisabolene in two steps from bisabolol was the final proof of the chemoselectivity of this reaction.

\section{Experimental}

FT-IR Spectra were recorded with a Perkin Elmer 298 spectrophotometer as film on $\mathrm{KBr}$ cells. ${ }^{1} \mathrm{H}$ NMR spectra were recorded with Varian GEMINI 300 (300.1MHz, Varian) or Bruker AC 300P (300.1 MHz) spectrometers $\mathrm{CDCl}_{3}$ was used as the solvent, with $\mathrm{Me}_{4} \mathrm{Si}$ (TMS) as internal standard. ${ }^{13} \mathrm{C}$ NMR spectra were obtained with a<smiles>CCCCC=CCC(C)(O)C1(CC)CC=C(C)CC1</smiles>

(-) - 8<smiles>CC1=CC[C@H](C(C)CCCC(C)(C)C)CC1</smiles>

OH (+) -9

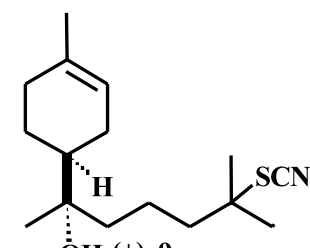

ÖH (+) $-9 \mathrm{a}$

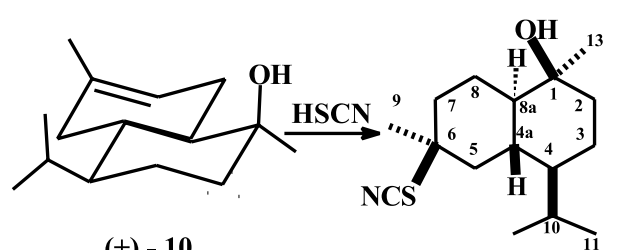

$( \pm)-10$

(土) -11

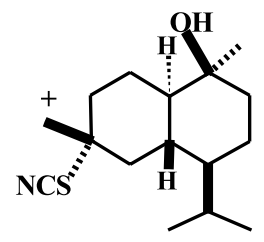

$( \pm)$ - 11a

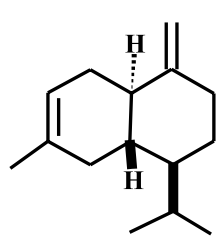

(土) -12

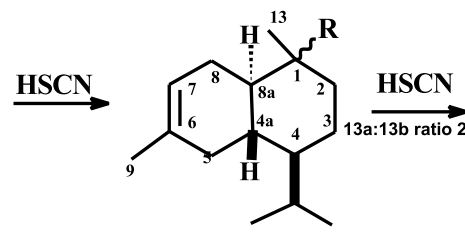

( \pm ) - $13 \quad$ R=NCS

$( \pm)$ - $14 \quad R=S C N$
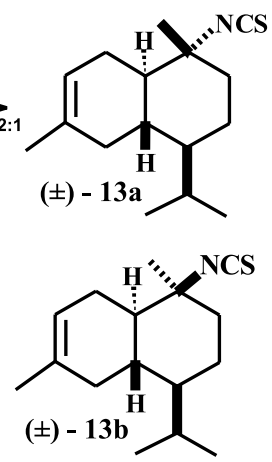

Figure 3. Addition of $\mathrm{HSCN}$ to terpenes posssessing polar groups. 


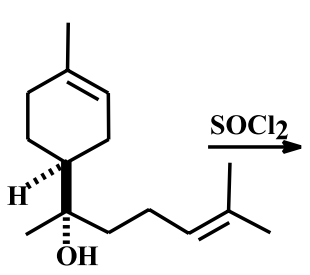

$(-)-8$
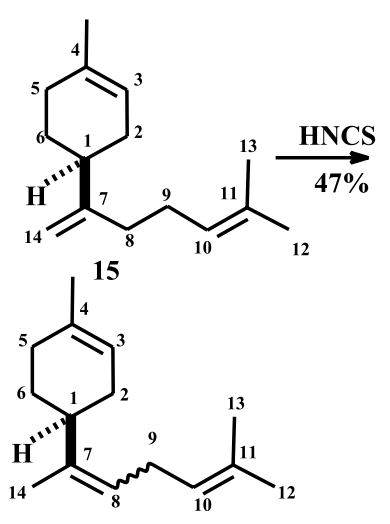

$15 \mathbf{a}$
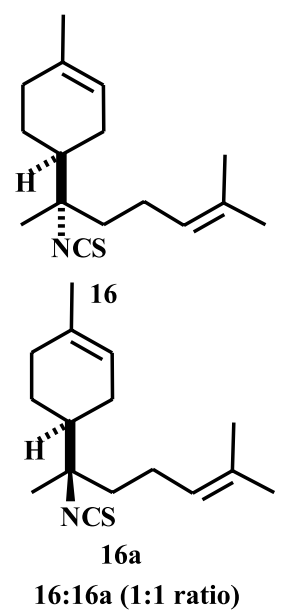

Figure 4. Synthetic route to isothiocyano bisabolene.

Varian GEMINI $300(75.5 \mathrm{MHz})$ or a Bruker AC300P $(75.5 \mathrm{MHz})$ spectrometers. $\mathrm{CDCl}_{3}(77.0 \mathrm{ppm})$ was used as internal standard. Methyl, methylene, methyne and carbon non bonded to hydrogen were discriminated using DEPT$135^{\circ}$ and DEPT $90^{\circ}$ spectra (Distortionless Enhancement by Polarization Transfer). 2D NMR spectroscopy was performed with standard $\mathrm{H}, \mathrm{H}$ correlation and $\mathrm{H}, \mathrm{X}$ correlation pulse sequences available in the spectrometers. Optical rotation values were measured with a Polamat A polarimeter and the reported data refer to the Na-line value using a $1 \mathrm{dm}$ cuvette. The GC/MS analyses were carried out using a HP-5890/5970 system equipped with a J\&W Scientific DB-5 fused silica capillary column $(25 \mathrm{~m}$ x 0.2 $\mathrm{mm} \times 0.33 \mathrm{~mm})$. Temperature program $1: 70{ }^{\circ} \mathrm{C}(0.5 \mathrm{~min}$. $)$ $-20^{\circ} \mathrm{C} / \mathrm{min}-180^{\circ} \mathrm{C}$; program $2: 55^{\circ} \mathrm{C}-20^{\circ} \mathrm{C} / \mathrm{min}-120^{\circ} \mathrm{C}$ (3 min.) $-1.5 \%$ min. $-150{ }^{\circ} \mathrm{C}$ (10min.) $-30^{\circ} / \mathrm{min} .-200{ }^{\circ} \mathrm{C}$ (10min.). The injector and detector temperature were $250{ }^{\circ} \mathrm{C}$. Helium was used as carrier gas. The MS were taken at $70 \mathrm{eV}$. Scanning speed was $0.84 \mathrm{scan} / \mathrm{s}$ from $\mathrm{m} / \mathrm{z} 40$ to 550 .

The numbering systems adopted to assign protons and carbon signals in the NMR spectra is depicted in Figures 1,2 and 3 which in some structures is different from the numbering following IUPAC nomenclature. The IUPAC names are in brackets in the experimental section.

Thiocyanic Acid: In an Aldrich atmosbag, a slurry of powdered $\mathrm{KSCN}(7.3 \mathrm{~g}, 75.0 \mathrm{mmol})$ in $30 \mathrm{~cm}^{3}$ of $\mathrm{CHCl}_{3}$ was triturated with $11.2 \mathrm{~g}(82.0 \mathrm{mmol})$ of $\mathrm{KHSO}_{4}$ in a mortar for 5 min. The HSCN chloroform solution was decanted and an additional $10 \mathrm{~cm}^{3}$ of $\mathrm{CHCl}_{3}$ was added to the solid mixture and then decanted. The combined solutions totalled $30 \mathrm{~cm}^{3}$.

Compounds ( \pm )-3 and ( \pm )-3a

A mixture of limonene (1)(Fluka, 0.408g) and HSCN / $\mathrm{CHCl}_{3}$ solution (prepared according to a method described above) was stirred at room temperature for $48 \mathrm{~h}$. After filtration, the solution was washed with water, dried $\left(\mathrm{Na}_{2} \mathrm{SO}_{4}\right)$, filtered and the solvent was removed under reduced pressure. The products were purified by column chromatography on silica gel eluting with hexane to yield a colourless oil $(0.390 \mathrm{~g}, 67 \%)$ of isothiocianosesquiterpene $( \pm)-\mathbf{3}$ and a more polar thiocyano $( \pm)-\mathbf{3 a}(0.180 \mathrm{~g}, 31 \%)$. Compound ( \pm )-3, [1-(1-methyl-1-isothiocyano-ethyl)-4methyl-3-cyclohexene]:IR (film) $v_{\text {max. }} / \mathrm{cm}^{-1} 2092$ (NCS). ${ }^{1} \mathrm{H}$ NMR ( $\mathrm{CDCl}_{3}$, partial assignment): $\delta 1.37(\mathrm{~s}, 3 \mathrm{H}, \mathrm{H}-9)$, 1.40 (s, 3H, H-8), 1.66 (s, 3H, H-10), 5.37 (s br, 1H, H-2). ${ }^{13} \mathrm{C}$ NMR $\left(\mathrm{CDCl}_{3}\right): \delta 23.2(\mathrm{C}-10), 24.2(\mathrm{C}-5), 26.4(\mathrm{C}-8)$, 26.8(C-3), 27.0 (C-9), 30.6(C-6), 44.5 (C-4), 64.0(C-7), 119.7 (C-2), 129.7 (NCS), 134.0 (C-1) GC/EIMS (70eV) m/z 195 (100), 136 (31), 121(79), 100 (50), 95(56), 93 (84), 81 (76), 67(57), 41(79). EIHRMS $\mathrm{m} / \mathrm{z}$ Found: $\mathrm{M}^{+}$195.10818; Calc. for $\mathrm{C}_{11} \mathrm{H}_{17} \mathrm{O}: 195.10817$. Compound ( \pm )-3a, [1-(1-methyl-1-thiocyano-ethyl)-4-methylcyclohexene]: IR (film) $v_{\text {max. }} / \mathrm{cm}^{-1} 2140.0(\mathrm{SCN}) .{ }^{1} \mathrm{H}$ NMR ( $\mathrm{CDCl}_{3}$, partial assignment): $\delta 1.50$ (s br, $\left.3 \mathrm{H}, \mathrm{H}-8\right), 1.55$ (s, 3H, H-9), 1.66 (s, 3H, H-10), 5.37 (s br, $1 \mathrm{H}, \mathrm{H}-2) .{ }^{13} \mathrm{C}$ NMR $\left(\mathrm{CDCl}_{3}\right): \delta 23.1$ (C-10), 24.9 (C-5), 26.2 (C-8), 27.3 (C-3), 27.3 (C-9), 30.9 (C-6), 44.1 (C-4), 59.9 (C-7), 112.2 (C-11), 119.6 (C-2), 134.2 (C-1). GC/EIMS (70 eV) $\mathrm{m} / \mathrm{z}$ 195 (7), 136 (34), 121(28), 95(30), 81 (100) 69 (39), 41(50).

Compounds ( \pm )-4 and ( \pm )-4a

A mixture of dihydrolimonene ${ }^{14}(2,0.207 \mathrm{~g})$ and $\mathrm{HSCN}$ $/ \mathrm{CHCl}_{3}$ solution (prepared according to a method described above) was stirred at room temperature for $48 \mathrm{~h}$. After filtration, the solution was washed with water, dried $\left(\mathrm{Na}_{2} \mathrm{SO}_{4}\right)$, filtered and the solvent was removed under reduced pressure. The products were purified by column chromatography on silica gel eluting with hexane to yield a colourless oil, $(0.100 \mathrm{~g}, 67 \%)$ as a mixture of compound 
isothiocianosesquiterpene $( \pm)-4$ and a more polar thiocyano $( \pm)-\mathbf{4 a}$ (ratio 4/4a =1.9:1) Compounds $( \pm)-\mathbf{4}$ (cis and trans), [ 4-isopropyl-1-methyl-1-isothiocyano-cyclohexane] IR (film) $v_{\text {max. }} / \mathrm{cm}^{-1} 2095.4$ (NCS). ${ }^{1} \mathrm{H} \mathrm{NMR}\left(\mathrm{CDCl}_{3}\right.$, partial assignment): $\delta 0.89$ (d, $J 7.4 \mathrm{~Hz}, 6 \mathrm{H}, \mathrm{H}-8$ and $\mathrm{H}-9$, cis or trans isomer), 1.05 (dd, $J 7.4,6 \mathrm{H}, \mathrm{H}-8$ and $\mathrm{H}-9$, cis or trans isomer), 1.61 (s, 6H, H-10, cis and trans isomer). GC/EIMS (70eV) m/z 197 (21), 161 (18), 139 (37), 97 (22), 55 (74). EIHRMS m/z Found: $\mathrm{M}^{+} 197.10236$; Calc. for $\mathrm{C}_{11} \mathrm{H}_{19} \mathrm{O}: 197.12382$. Compound $( \pm)-\mathbf{4 a}$ (cis and trans), [4-isopropyl-1-methyl-1-thiocyano-cyclohexane] IR (film) $v_{\text {max. }} / \mathrm{cm}^{-1} 2148(\mathrm{SCN}) .{ }^{1} \mathrm{H} \mathrm{NMR}\left(\mathrm{CDCl}_{3}\right.$, partial assignment): $\delta 0.89$ (d, J 7.1 Hz, 6H, H-8 and H-9, cis or trans isomer), $0.98(\mathrm{~d}, J 7.1 \mathrm{~Hz}, 6 \mathrm{H}, \mathrm{H} 8$ and $\mathrm{H}-9$, cis or trans isomer), 1.37 (s, 6H, H-10, cis and trans isomers). GC/EIMS (70eV) m/z 139 (29), 83 (100), 55 (67).

(土)-Cadinol (6): - (1b, 4b, 4ab, 8aa)-1,6 - dimethyl - 4 (1-methylethyl) - 1,2,3,4,4a,5,8,8a-octahydro-1- methoxynaphthalene)

To a solution of $( \pm)$-cadinol $(\mathbf{1 0}, 0.060 \mathrm{~g})$ in anhydrous THF under argon at $-78^{\circ} \mathrm{C}$ was added sodium hydride $(0.070 \mathrm{~g})$ and the mixture was stirred for $10 \mathrm{~min}$. Methyl iodide was then slowly added and the mixture stirred for $2.5 \mathrm{~h}$. Water was added in the solution and the resulting mixture was extracted with $\mathrm{Et}_{2} \mathrm{O}$ and the organic layer was dried and evaporated. The crude product was purified by column chromatography using $\mathrm{Et}_{2} \mathrm{O}$ to give $( \pm)-6(0.060$ $\mathrm{g} ; 94 \%)$ as a colorless oil. ${ }^{1} \mathrm{H}$ NMR $\left(\mathrm{CDCl}_{3}\right.$, partial assignment): $\delta 0.75$ (d, J 7.4 Hz, 3H, H-12), 0.90 (d, J 7.4 Hz, 3H, H-11), 1.08 (s, 3H, H-13), 1.55 (s, 3H, H-9), 3.09 (OMe), 5.40 (s br, 1H, $\mathrm{H}-7$ ). EIHRMS $m / z$ Found: $\mathrm{M}^{+}$ 236.21404; Calc. for $\mathrm{C}_{16} \mathrm{H}_{28} \mathrm{O}: 236.2140$.

\section{Compounds 9 and $\mathbf{9 a}$}

HNCS chloroform solution $\left(20 \mathrm{~cm}^{3}\right)$ was added to (-)-Bisabolol (2) (0.500 g) in chloroform $\left(5 \mathrm{~cm}^{3}\right)$. The mixture was stirred at room temperature for 6 days. The reaction was filtered and concentrated in vacuo. Purification of the residue by silica gel column chromatography using hexane:ethyl acetate $(80: 20 \mathrm{v} / \mathrm{v})$ gave the isothiocyanate 9 $(0.134 \mathrm{~g} ; 24 \%)$ as a yellow oil and hexane:ethyl acetate $(75$ : $25 \mathrm{v} / \mathrm{v})$ gave the thiocyanate $9 \mathrm{a}(0.065 \mathrm{~g} ; 11 \%)$ as a yellow oil. Compound 9 [ 1-methanol- $\alpha$, 4- dimethyl- $\alpha$-(4-methyl-4 isothiocyanopentanyl)-3-cyclohexene ]: ${ }^{1} \mathrm{H} \mathrm{NMR}\left(\mathrm{CDCl}_{3}\right.$, partial assignment): $\delta 1.10(\mathrm{~s}, 3 \mathrm{H}, \mathrm{H}-14), 1.38$ (s, 3H, H-12 and $\mathrm{H}-13), 1.45$ (t, 2H, H - 10), 1.64 (s, 3H, H- 15), 5.35 (m, $1 \mathrm{H}, \mathrm{H}-3) .{ }^{13} \mathrm{C} \mathrm{NMR}\left(\mathrm{CDCl}_{3}\right): \delta 23.2(\mathrm{C}-15), 28.7(\mathrm{C}-14)$, 28.9 (C - 12 and C-13), 39.9 (C - 8), 43.1 (C - 1), 43.3 (C 10), 61.3 (C - 11), 74.0 (C - 7), 120.4 (C - 3), 130.3 (NCS),
134.2 (C - 4). Compound 9a [1-methanol- $\alpha$, 4- dimethyl- $\alpha$ (4-methyl-4 thiocyanopentanyl)-3-cyclohexene]: ${ }^{1} \mathrm{H}$ NMR $\left(\mathrm{CDCl}_{3}\right.$, partial assignment): $\delta 1.10(\mathrm{~s}, 3 \mathrm{H}, \mathrm{H}-14), 1.50$ (s, 3H, H-12 and H-13), 1.64 (s, 3H, H - 15), 5.35 (m, 1H, $\mathrm{H}-3) .{ }^{13} \mathrm{C} \mathrm{NMR}\left(\mathrm{CDCl}_{3}\right): \delta 23.2(\mathrm{C}-15), 28.7(\mathrm{C}-14), 40,5$ (C - 8), 43.6 (C - 1), 43.9 (C - 10), 56.0 (C - 11), 74.1 (C - 7), $111.9(\mathrm{SCN}), 120.4(\mathrm{C}-3), 134.2(\mathrm{C}-4)$.

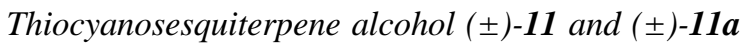

A mixture of $( \pm)-\mathbf{1 0}^{9}(0.045 \mathrm{~g} ; 0.2 \mathrm{mmol})$ and $\mathrm{HSCN} /$ $\mathrm{CHCl}_{3}$ solution (prepared according to a method described above) was stirred at room temperature for 7 days. After filtration, the solution was washed with water, dried $\left(\mathrm{Na}_{2} \mathrm{SO}_{4}\right)$, filtered and the solvent removed under reduced pressure. The products were purified by column chromatography on silica gel eluting with hexane: ethyl acetate (97.5: $2.5 \mathrm{v} / \mathrm{v})$ to yield a colourless oil, $0.016 \mathrm{~g} \mathrm{(36 \% )}$ of compound thiocianosesquiterpene $\mathbf{1 1}$ and eluting with hexane: ethyl acetate $(92.5: 7.5 \mathrm{v} / \mathrm{v})$ to yield $(0.016 \mathrm{~g}, 36$ $\%$ ) of compound thiocianosesquiterpene 11a. Thiocyanosesquiterpene ( \pm$)-11[1 \beta, 4 \beta, 4 a \beta, 6 \beta, 8 a \alpha-6$-thiocyano1,6 - dimethyl - 4 - (methylethyl) - decahydro - 1 naphthalenol)]: IR (film) $v_{\text {max. }} / \mathrm{cm}^{-1} 3482.1(\mathrm{SCN}) .{ }^{1} \mathrm{H} \mathrm{NMR}$ $\left(\mathrm{CDCl}_{3}\right.$, partial assignment): $\delta 0.79(\mathrm{~d}, J 7 \mathrm{~Hz}, 3 \mathrm{H}, \mathrm{H}-12)$, 0.90 (d, J 7Hz, 3H, H-11), 1.19 (s, 3H, H-13), 1.53 (s, 3H, $\mathrm{H}-9) .{ }^{13} \mathrm{C} \mathrm{NMR}\left(\mathrm{CDCl}_{3}\right): \delta 14.9$ (C-12), 19.2 (C-3), 21.3 (C-11), 22.7 (C-8), 24.2 (C-9), 26.1 (C-10), 28.8 (C-13), 35.8 (C-4a), 38.6 (C-5), 40.6 (C-2), 42.6 (C-7), 47.9 (C4), $49.6\left(\mathrm{C}-8 \mathrm{a}_{\mathrm{a}}\right), 56.4(\mathrm{C}-6), 119.9(\mathrm{SCN})$. Compound ( \pm )11a: $(1 \beta, 4 \beta, 4 a \beta, 6 \alpha, 8 a \alpha)-6$-thiocyano - 1,6 - dimethyl 4 - (1-methylethyl) - decahydro - 1 - naphthalenol): IR (film) $v_{\text {max. }} / \mathrm{cm}^{-1} 3510.1(\mathrm{SCN}) .{ }^{1} \mathrm{H} \mathrm{NMR}\left(\mathrm{CDCl}_{3}\right.$, partial assignment): $\delta 0.78(\mathrm{~d}, J 7.1 \mathrm{~Hz}, 3 \mathrm{H}, \mathrm{H}-12), 0.90(\mathrm{~d}, J 7.1 \mathrm{~Hz}$, 3H, H-11), 1.19 (s, 3H, H-13), 1.63 (s, 3H, H-9). ${ }^{13} \mathrm{C} \mathrm{NMR}$ $\left(\mathrm{CDCl}_{3}\right): \delta 15.0(\mathrm{C}-12), 19.1(\mathrm{C}-3), 21.4(\mathrm{C}-11), 21.9(\mathrm{C}-$ 8), 26.2(C-10, 28.7 (C-13), 32.7 (C-9), 34.8 (C-4a), 37.6 (C-5), 40.5 (C-7), 41.6(C-2), 47.4(C-8a), 50.0 (C-4), 57.9 (C-6), 70.4(C-1), 112.0 (SCN). EIHRMS $m / z$ Found: $\mathrm{M}^{+}$ at $m / z$ 281.16151; Calc. for $\mathrm{C}_{16} \mathrm{H}_{27}$ NOS: 281.181336 .

\section{(士)-Cadinene derivatives $13 a / 13 b$ and $14 a$}

A mixture of cadinene $( \pm)-12(0.050 \mathrm{~g})$ and $\mathrm{HSCN} / \mathrm{CHCl}_{3}$ solution (prepared according to a method described above) was stirred at room temperature for $24 \mathrm{~h}$. After filtration, the solution was washed with water, dried $\left(\mathrm{NaSO}_{4}\right)$, filtered and the solvent was removed under reduced pressure. The products were purified by column chromatography on silica gel eluting with hexane to yield a colourless oil $(0.013 \mathrm{~g}$, $19 \%$ ) of isothiocyanosesquiterpene $\mathbf{1 3 a}$ / $\mathbf{1 3 b}$ and eluting with hexane: ethyl acetate $(99.5: 0.5 \mathrm{v} / \mathrm{v})$ to yield $(0.016 \mathrm{~g}, 19 \%)$ 
of compound thiocyanosesquiterpene 14. ${ }^{1} \mathrm{H}$ NMR of 13a/13b $\left(\mathrm{CDCl}_{3}\right.$, partial assignment): $\delta 0.74(\mathrm{~d}, J 7 \mathrm{~Hz}, 3 \mathrm{H}$, $\mathrm{H}-8)$ ), 0.81 (d, $J 7 \mathrm{~Hz}, 3 \mathrm{H}, \mathrm{H}-12), 0.91$ (d, $J 7 \mathrm{~Hz}, 3 \mathrm{H}$, H-11), 0.93 (d, J 7 Hz, 3H, H-11, 1.26 (s, 3H, H-13), 1.36 (s, 3H, H-13), 155 (s, 3H, H-8), 1.64 (s, 3H, H-9), 5.41(s br, $2 \mathrm{H}, \mathrm{H}-7) .{ }^{13} \mathrm{C} \mathrm{NMR}\left(\mathrm{CDCl}_{3}\right): \delta 15.1\left(\mathrm{CH}_{3}, \mathrm{C}-12\right), 19.7$ and $19.8\left(\mathrm{CH}_{2}, \mathrm{C}-3\right), 20.7\left(\mathrm{CH}_{3}, \mathrm{C}-13\right), 21.6$ and $21.7\left(\mathrm{CH}_{3}, \mathrm{C}-\right.$ 11), 23.3 and $23.4\left(\mathrm{CH}_{3}, \mathrm{C}-9\right), 26.1$ and $26.3\left(\mathrm{CH}_{2}, \mathrm{C}-10\right)$, 26.4 and $26.7\left(\mathrm{CH}_{2}, \mathrm{C}-8\right), 27.5\left(\mathrm{CH}_{3}, \mathrm{C}-13\right), 35.0$ and 35.5 $(\mathrm{CH}, \mathrm{C}-4 \mathrm{a}), 36.2\left(\mathrm{CH}_{2}, \mathrm{C}-5\right), 46.5$ and46.7 (CH, C-8a), 64.4 and 64.8 (A, -1), 119.5 and $119.7(\mathrm{CH}, \mathrm{C}-7), 129.8$ (NCS), 132.8 and 132.9 (C, C-6).

\section{Compounds 16 and 16 a}

To $1.200 \mathrm{~g}$ of (-)-bisabolol (8) in anhydrous pyridine $\left(0.5 \mathrm{~cm}^{3}\right)$ was added slowly $\mathrm{SOCl}_{2}\left(2.5 \mathrm{~cm}^{3}\right)$ with stirring at $0{ }^{\circ} \mathrm{C}$ for $48 \mathrm{hs}$. The resulting solution was extracted with $\mathrm{Et}_{2} \mathrm{O}$ and the organic layer was dried and evaporated. The crude product was purified by column chromatography using hexane to give the mixture of bisabolene (15 and 15a) $(0.600 \mathrm{~g} ; 56 \%)$ as a colourless oil. To a mixture of bisabolenes $(0.100 \mathrm{~g})$ in chloroform $\left(1 \mathrm{~cm}^{3}\right)$ was added a HNCS - chloroform solution $\left(10 \mathrm{~cm}^{3}\right)$ prepared as described above. The mixture was stirred at room temperature for $2 \mathrm{~h}$ while controlling the reaction by GC. The reaction was filtered and concentrated in vacuo. Purification of the residue by column chromatography on silica gel using hexane:ethyl acetate $(95: 5 \mathrm{v} / \mathrm{v})$ gave the isothiocianate 14 and $\mathbf{1 4 a}(0.060 \mathrm{~g}, 47 \%$ yield) as a 1:1 mixture. Comparison with literature data ${ }^{11}$ allowed the discrimination of the signals into two sets which were assigned to compounds $\mathbf{1 6}$ and 16a without establishing the relative stereochemistry at carbon 7: Compound 16 or 16a: ${ }^{1} \mathrm{H} \mathrm{NMR}\left(\mathrm{CDCl}_{3}\right.$, partial assignment): $\delta 1.32(\mathrm{~s}, 3 \mathrm{H}$, H-14), 1.63 (s, 3H, H-13), 1.66 (s, 3H, H-12), 1.70 (s, 3H, $\mathrm{H}-15), 5.10(\mathrm{~m}, 1 \mathrm{H}, \mathrm{H}-10), 5.38$ (m, 1H, H-3). ${ }^{13} \mathrm{C}$ NMR $\left(\mathrm{CDCl}_{3}\right): \delta 17.7(\mathrm{C}-13), 22.8(\mathrm{C}-14), 23.2(\mathrm{C}-15), 25.7(\mathrm{C}-$ 12), 42.8 (C - 1), 67.2 (C - 7), 119.8 (C - 3), 123.2 (C - 10), 132.9 (C - 4), 134.5 (C - 11). Compound 16a or 16: ${ }^{1} \mathrm{H}$ NMR $\left(\mathrm{CDCl}_{3}\right.$, partial assignment): $\delta 1.34(\mathrm{~s}, 3 \mathrm{H}, \mathrm{H}-14), 1.63(\mathrm{~s}$, $3 \mathrm{H}, \mathrm{H}-12$ ), 1.66 (s, 3H, H-13), 1.70 (s, 3H, H-15), 5.10 (m, 1H, H-10), $5.38(\mathrm{~m}, 1 \mathrm{H}, \mathrm{H}-3) .{ }^{13} \mathrm{C} \mathrm{NMR}\left(\mathrm{CDCl}_{3}\right)$ : $\delta 17.7$ (C-13), 22.7 (C-14), 23.5 (C-15), 25.7 (C-12), 43.2 (C - 1), 67.0 (C - 7), 120.1(C - 3), 123.2 (C - 10), 132.9 $(\mathrm{C}-4), 134.2(\mathrm{C}-11)$.

\section{Acknowledgements}

The authors are indebted to FAPESP (Fundação de Amparo a Ciência do Estado de S. Paulo) for financial support. C. M. A. de Oliveira and C. C. da Silva are thankful to CAPES/PICD for scholarships. The authors wish to express their gratitude to the referees for helpful suggestions and to the JBCS editorial staff for patience and understanding.

\section{References}

1. Drobnica, L.; Kristían, P.; Augustín, J. In The chemistry of the cyanates and their thio derivatives, Saul Patai Ed., John Wiley \& Sons, New York.

2. a) Edenborough, M. S.; Herbert, R. B. Nat. Prod. 1988, 229; b) Faulkner, D. J. Nat. Prod. 1994, 355; c) ibid 1993, 497; d) ibid, 1992, 323; d) ibid, 1991,97; f) ibid, 1990, 269; g) ibid, 1988, 613; h) Fraga, B. M. Nat. Prod. Rep. 1994, 533.

3. Among others a) Piers, E.; Young, B.W. A.; Rettig, S. J. Tetrahedron 1987,43(23), 5521; b) Piers, E.; Yeung, B. W. Can. J. Chem. 1986, 64, 2475; c) Chenera, B.; Chuang, C. P.; Hart, D. J.; Lai, C. S. J. Org. Chem. 1992, 57, 2018.

4. da Silva, C. C.; Almagro, V.; Zukerman-Schpector, J.; Castellano, E. E.; Marsaioli, A. J. J. Org. Chem. 1994, 59, 2880.

5. da Silva, C. C.; Almagro, V.; Marsaioli, A. J. Tetrahedron Lett. 1993, 34, 6717.

6. Martin, V. S.; Woodward, S. S.; Katsuki, T. Yamada, Y.; Ikeda, M.; Sharpless, K. B. J. Am. Chem. Soc. 1981, 103, 6237.

7. Rakels, J. L.; Straathof, A. J. J.; Heijnin, J. J. Enzyme Microb. Technol. 1993, 15, 1051.

8. Diveley, W. R.; Buntin, G. A.; J. Org. Chem. 1969 , $34,616$.

9. Queiroga, C. L.; Ferracini, V. L.; Marsaioli, A. J. Phytochemistry 1996, 42, 1097.

10. (-)Bisabolol (8) $[(\alpha S, 1 S)$-1-methanol- $\alpha$,4-dimethyl- $\alpha$ (4-methyl-3-pentenyl-3-cyclohexene] was obtained from commercial candeia oil (CITRÓLEO - S.Paulo, SP, Brazil).

11. Sullivan, B. W.; Faulkner, D. J.; Okamoto, K. T.; Chen, M. H. M.; Clardy, J. J. Org. Chem. 1986, 51, 5134.

12. Dubois, J. E.; Lomas, J. S. Tetrahedron Lett. 1971, 7, 599.

13. Delay, F.; Ohloff, F. Helv. Chem. Acta 1979, 62, 326.

14. A sample of dihydrolimonene was kindly provided by Prof. Marcio C. S. de Mattos from IQ/UFRJ, RJ, Brazil.

Received: March 10, 2000

Published on the web: August 15, 2001

FAPESP helped in meeting the publication costs of this article. 